STUDIA POLONIJNE

T. 40. LUBLIN 2019

DOI: http://dx.doi.org/10.18290/sp.2019.7

EWA JASZEWSKA

\title{
SYTUACJA SPOLECZNA KOBIET NA DALEKIM WSCHODZIE UTRWALONA W CZASOPISMACH I WSPOMNIENIACH POLAKÓW NA PRZELOMIE XIX I XX WIEKU
}

Polacy, a zwłaszcza Polki, zarówno w kraju, jak i na Dalekim Wschodzie, z ogromną uwagą przyglądali się uporczywym staraniom, przede wszystkim Chinek oraz Japonek, o równouprawnienie i poszanowanie ich godności. Wspomniane zaciekawienie znajdowało swoje odzwierciedlenie przeważnie w artykułach publikowanych na łamach polskich czasopism, które ukazywały się w kraju i zagranicą. W tym miejscu na szczególną uwagę zasługują takie tytuły, jak „Daleki Wschód”, który wydawano w Harbinie (obecnie Chiny Północno-Wschodnie), a także „Echo z Dalekiego Wschodu”, organ prasowy Związku Młodzieży z Dalekiego Wschodu, publikowany w latach 1938-1939 w Warszawie ${ }^{1}$. Ciekawym odstępstwem od tej reguły są książki napisane przez Konstantego Symonolewicza ${ }^{2}$, jak również

Mgr Ewa JASZEWSKA - doktorantka, Instytut Historii i Politologii na Wydziale Filologiczno-Historycznym Akademii Pomorskiejw Słupsku; jaszewska@poczta.onet.pl

${ }^{1}$ W. TheIss, Dzieci syberyjskie. Dzieje polskich dzieci repatriowanych z Syberii i Mandżurii w latach 1919-1923, Warszawa 1992, s. 201; K. Yong-Deog, Kolonia polska w Mandżurii $1897-$ 1949, Kraków 2001, s. 99.

2 Konstanty Symonolewicz (1884-1952) - orientalista, sinolog, rosyjski i polski urzędnik konsularny, dyplomata i publicysta. W 1920 r. rozpoczął pracę w szeregach polskiej służby zagranicznej. Powierzano mu wiele stanowisk, głównie w Harbinie (1920-1930) - wicekonsula, konsula, zastępcy delegata RP na Chiny z siedzibą w Harbinie, kierownika delegacji RP w Harbinie, kierownika konsulatu w Harbinie (1928-1930), kierownika konsulatu generalnego w Mińsku (1930-1932) oraz radcy w polskim poselstwie w Moskwie (1933). W kolejnych latach zajął się publicystyką, umieszczając swoje artykuły poświęcone tematyce dalekowschodniej m.in. w „Kurierze Porannym”, „Sybiraku” czy „Przeglądzie Powszechnym”. Jednocześnie wykładał w Instytucie Studiów Handlowych i Orientalistycznych w Warszawie. Opublikował: Miraże mandżurskie, Warszawa 1932 oraz Moi Chińczycy. 18 lat w Chinach, Warszawa 1938 (S. ŁozA, Czy wiesz kto to jest?, Warszawa 1938, s. 858; W. SkóRA, Organizacja i pierwszy okres działalności polskich konsulatów w Harbinie i Władywostoku w latach 1920-1924, [w:] Polskie ślady na Dalekim Wschodzie. Polacy w Harbinie, red. A. Furier, Szczecin 2008, s. 84-85; S. Bursewicz, Mandżuria i Syberia w piśmiennictwie Konstantego Symonolewicza, [w:] Problemy społeczno-gospodarcze Syberii, red. M. Pietrasiak, M. Stańczyk, Łódź 2011, s. 179). 
wspomnienia Emilii Czajewskiej ${ }^{3}$ - Polki urodzonej w Harbinie - przechowywane w zbiorach Książnicy Pomorskiej w Szczecinie. Z tego względu fragmenty przytoczonych publikacji stanowią podstawę źródłową niniejszego tekstu.

W celu dokładnego opisania zapatrywań dużej części mieszkańców Dalekiego Wschodu na prawa kobiet oraz ich rolę w społeczeństwie, zwłaszcza na terenie Chin i Japonii, panujących na początku XX wieku, warto posłużyć się fragmentem chińskiego wiersza z tego okresu: „Gdy urodzi się syn włóż go do kołyski; / Spowiń w kosztowne powijaki; / Daj mu zabawki z kosztownego kamienia. / Gdy urodzi się córka, niech leży na ziemi; / Owinięta w szmaty; / Niech bawi się kawałkiem wypalonej gliny". Fragment ten pochodzi z artykułu Franciszki Arkin ${ }^{4}$ pod tytułem Kobieta Dalekiego Wschodu, opublikowanego w gazecie „Daleki Wschód”s. Wspomniany periodyk ukazywał się w latach trzydziestych XX wieku jako organ

${ }^{3}$ Emilia CzajEwska (1921-1981) - przyszła na świat w małej osadzie kolejowej Handachetsy w północnej Mandżurii, leżącej na wschodnim odcinku Kolei Wschodniochińskiej, który łączył Harbin z Władywostokiem. W miasteczku tym mieszkało kilkudziesięciu polskich osadników. W okolicy znajdował się duży tartak drzewny, należący do olbrzymiej koncesji leśnej Władysława Kowalskiego (1870-1940). Wśród pracowników umysłowych tego przedsiębiorstwa zdecydowaną większość stanowili Polacy. Właściciel koncesji wspomagał w znacznym stopniu poczynania społeczno-kulturalne Polonii mandżurskiej. Koncesję zabrali mu Japończycy w 1936 r. Autorka przytaczanych wspomnień wychowywała się w Harbinie pod opieką stryja, Adama Czajewskiego (1876-1955), przedstawiciela licznego grona polskich inżynierów i techników zatrudnionych przy budowie Kolei Wschodniochińskiej, a także ciotki, Jadwigi Czajewskiej (1880-1934). Prowadziła wygodne życie, korzystając z pomocy chińskiego służącego, który mieszkał w ich domu razem ze swoją małżonką. Była absolwentką Gimnazjum im. Henryka Sienkiewicza w Harbinie, a ponadto ukończyła anglojęzyczny College YMCA w tym samym mieście. W czasie swojego pobytu w Mandżurii była naocznym świadkiem przemian zachodzących nie tylko w społeczności polskiej, lecz także chińskiej. Na początku lat pięćdziesiątych XX wieku, podobnie jak większość Polaków zamieszkujących Mandżurię, opuściła Chiny i osiedliła się w Polsce na terenie tzw. Ziem Odzyskanych (Książnica Pomorska w Szczecinie [dalej: KPS], Zbiory specjalne [dalej: ZS], sygn. 3390, Wspomnienia z lat młodości w Harbinie (1921-1945) Emilii Czajewskiej, oprac., ilustracjami, dokumentami i komentarzem opatrzył J. Czajewski, Szczecin 1985, k. 1-5; Archiwum Państwowe w Szczecinie, Wojewódzki Oddział Państwowego Urzędu Repatriacyjnego w Szczecinie, sygn. 53, Sprawozdanie z przybyłych dwóch transportów z reemigrantami z Mandżurii na Punkt Etapowy nr 1 P.U.R. Szczecin i wyszczególnienie miejsca osiedlenia i pracy, Szczecin, 22 sierpnia 1949 roku, k. 13-16; K. Symonolewicz, Miraże mandżurskie, Warszawa 1932, s. 286).

${ }^{4}$ Co ciekawe, Franciszka Arkin, podobnie jak Emilia Czajewska, prowadziła wygodne i zamożne życie w Harbinie. Wynikało to z tego, że była żoną inż. Arkina, który w tym mieście kierował składem wyrobów wełnianych należącym do białostockiego przedsiębiorstwa Trylling \& Company, założonego przez Oswalda Tryllinga (Studia i materiały do dziejów miasta Białegostoku, red. J. Joka, J. Antoniewicz, H. Majecki, Białystok 1968, s. 330).

${ }^{5}$ F. Arkin, Kobieta Dalekiego Wschodu, „Daleki Wschód” 1935, nr 1, s. 8. 
prasowy Stowarzyszenia „Gospoda Polska” z siedzibą w Harbinie. Początkowo nosił nazwę „Listy Harbińskie”. Ten bogato ilustrowany, a dodatkowo posiadający szeroki profil tematyczny, miesięcznik był jednym z najlepszych czasopism polskich na Dalekim Wschodzie ${ }^{7}$.

Wypada dodać, że początki polskiej obecności na Dalekim Wschodzie sięgają końca XIX wieku i ściśle wiążą się z Harbinem, miastem leżącym nad rzeką Sungari w Mandżurii, a obecnie na obszarze Chin Północno-Wschodnich, które zostało założone 16 maja 1898 r. przez polskiego inżyniera Adama Szydłowskiego ${ }^{8}$. Tam też od czasu budowy Kolei Wschodniochińskiej ${ }^{9}$ (1897-1903) znajdowało się największe

6 „Gospoda Polska” była stowarzyszeniem kulturalno-oświatowym działającym na terenie Harbina w latach 1907-1949. Stowarzyszenie to zainicjowało utworzenie pierwszej polskiej szkoły początkowej, zajmowało się prowadzeniem kursów języka polskiego, a także zbiórkami pieniędzy na cele edukacyjne i charytatywne (A. WinIARz, Główne kierunki i formy aktywności Polaków w Mandżurii w latach 1897-1949, [w:] Polskie ślady na Dalekim Wschodzie, s. 32). W ramach stowarzyszenia, jako osobne sekcje, rozwinęło swoją działalność wiele mniejszych organizacji o szerokim wachlarzu celów i zadań, począwszy od edukacyjnych, młodzieżowych (Związek Młodzieży Polskiej), kulturalnych (Koło Teatralne), a skończywszych na zespołach sportowych, w tym drużynie hokejowej. Jednak aktywność tego stowarzyszenia nie skupiała się wyłącznie na zadaniach o charakterze społecznym i dobroczynnym, lecz także na prowadzeniu działalności gastronomicznej. Jeszcze w maju 1918 r. właściciele „Gospody Polskiej” zapraszali potencjalnych klientów na „obiady domowe i kolacje” w budynku przy ulicy Głuchej, w którym następnie powstał polski konsulat („Praca. Pismo Postępowe i Demokratyczne" 1918, nr 8, s. 10).

7 A. WinIarz, Bibliografia prasy polskiej na Dalekim Wschodzie w latach 1917-1949, „,Kwartalnik Historii Prasy Polskiej” 25(1986), nr 1, s. 126.

${ }^{8}$ Archiwum Akt Nowych [dalej: AAN], Kolonia Polska w Mandżurii [dalej: KPM], sygn. 66, Historia kolonii polskiej w Mandżurii, oprac. K. Krąkowski, k. 7.

${ }^{9}$ Kolej Wschodniochińska była linią kolejową, która przebiegała przez północno-wschodnie Chiny, a więc Mandżurię. Została zbudowana w latach 1897-1903, aby połączyć rosyjskie miasta Czyta i Władywostok. Jej południowa odnoga, znana jako Kolej Południowomandżurska, stanowiła jeden z powodów wojny rosyjsko-japońskiej i drugiej wojny chińsko-japońskiej z lat 1937-1945. Oficjalnie budowę kolei finansował stworzony specjalnie w tym celu Bank Rosyjsko-Chiński, z kapitałem pochodzącym głównie z Francji. Budowa kolei, rozpoczęta z inicjatywy ministra finansów Siergieja Witte (1849-1915), posłużyła Rosjanom jako pretekst do dalszej ekspansji na obszarze Dalekiego Wschodu. Pomimo przyjętego przez Chiny $1435 \mathrm{~mm}$ standardu rozstawu toru, na trasie Kolei Wschodniochińskiej Rosjanie wymogli swój 1524 mm standard. W budowie kolei brali udział polscy inżynierowie, w tym Adam Szydłowski. Na centrum administracyjne Kolei Wschodniochińskiej i Strefy Kolejowej obrano Harbin. Przy budowie zatrudniono wielu Polaków, wcześniej zatrudnionych przy budowie Kolei Transsyberyjskiej, a także zesłańców politycznych z 1863 r. (S.Y. WiTTE, The Memoirs of Count Witte, thum. A. Yarmolinsky, Garden City 1921, s. 95-96; E. KaJDAŃsKi, Korytarz. Burzliwe dzieje Kolei Wschodniochińskiej 1898-1998, Warszawa 2000, s. 11-58; M. MoustAFINE, Secrets and Spies. The Harbin Files, London 2002, s. 2-10). 
skupisko Polaków na Dalekim Wschodzie ${ }^{10}$. Już w 1907 r. ich liczbę szacowano na 7 tys. osób ${ }^{11}$. Co więcej, w okresie od 1917 do 1920 r. na terenie Harbina ${ }^{12}$ przebywało aż 14 tys. naszych rodaków ${ }^{13}$, a łącznie co najmniej 20 tys. w całej Mandżurii ${ }^{14}$. W kolejnej dekadzie mandżurskie miasta zalała fala rosyjskich uchodźców, uciekających przed bolszewikami. W tym samym czasie, według oficjalnych danych polskiego Ministerstwa Spraw Zagranicznych, na obszarze całych Chin znajdowało się około 5 tys. Polaków, w tym blisko 3 tys. w Harbinie ${ }^{15}$. Dla porównania - ówczesną liczbę Japończyków, którzy w 1932 r. przejęli kontrolę nad miastem, oceniano na blisko 4 tys. osób ${ }^{16}$. Jednak z biegiem lat liczba polskich obywateli w Mandżurii stale się zmniejszała. W 1930 r. w Harbinie mieszkało już tylko niecałe 2 tys. Polaków ${ }^{17}$. Podobne informacje na łamach czasopisma „Echo z Dalekiego Wschodu”

${ }^{10}$ KPS, ZS, sygn. 3399, Polska wyspa na Żółtym Morzu, Tadeusz Szukiewicz, Kraków, 28 listopad 1949, k. 178-179.

11 M. Cabanowski, Tajemnice Mandżurii. Polacy w Harbinie, Warszawa 1993, s. 13.

${ }^{12} \mathrm{~W}$ dwudziestoleciu międzywojennym głównymi miastami Mandżurii były Shenyang oraz Harbin. W tamtym czasie położone na południu Shenyang, a wcześniej Mukden albo Fengtien, zamieszkiwało ponad 300 tys. osób. Natomiast większy od niego i zlokalizowany na północy Harbin liczył przeszło 400 tys. mieszkańców (B.L. Putnam Weale, The Coming Struggle in Eastern Asia, London 1908, s. 115; W. SKóRA, Placówki MSZ Drugiej Rzeczypospolitej w Harbinie w latach 1920 1941 na tle dziejów Chin i Mandżurii (Mandżukuo). Szkic do problemu, [w:] Na szlakach dwóch światów. Studia ofiarowane Profesorowi Jerzemu Hauzińskiemu w 45-lecie pracy naukowej i dydaktycznej, red. A. Teterycz-Puzio, Słupsk 2016, s. 679). W 1938 r. szacowano liczebność Harbina na około 450 tys. osób (E.J. Reyman, Encyklopedia nauk politycznych, t. III, Warszawa 1938, s. 866-867). Z kolei znacznie bardziej dokładne dane zebrane rok później przez japońską administrację Harbina precyzują tę liczbę na 457980 tys. mieszkańców, wśród których większość stanowili Chińczycy (Bureau of Information Manchukuo State Council, An Outline of the Manchukuo Empire, 1939, Dairen 1939, s. 25-28). Wcześniej, bo w połowie lat dwudziestych XX wieku, Harbin był zamieszkały przez ponad 200 tys. osób. Najliczniejszą grupę jego mieszkańców stanowili Rosjanie, których liczbę szacowano na 120 tys. osób. Tak duży napływ Rosjan wynikał zapewne z niedawnej wojny domowej i porażki tzw. białych Rosjan (J.J. STEPHAN, The Russian Fascists. Tragedy and Farce in Exile, 1925 1945, London 1978, s. 37).

13 В.А. Анучин, Географические очерки Маньчжурии, Москва 1948, s. 39; А. JABŁoŃskA, K. Krąkowski, Z dziejów Polonii Harbińskiej, „Przegląd Orientalistyczny” 1961, nr 2(38), s. 160162; В.П. Петров, Город на Сунгари, Вашингтон 1984, s. 8-10.

${ }^{14}$ E. KAJDAŃSKI, Chiny. Leksykon. Historia, gospodarka, kultura, Warszawa 2005, s. 87.

${ }_{15}$ Archiwum Archidiecezjalne w Gnieźnie [dalej: AAG], Archiwum Prymasa Polski [dalej: APP], sygn. 65, „Tygodnik Polski” 1926, nr 246, k. 17; Wychodźstwo polskie w poszczególnych krajach. Materiaty opracowane na podstawie sprawozdań konsularnych przez referat emigracyjny w Wydziale Administracyjno-Paszportowym Departamentu Konsularnego MSZ (kwiecień 1926), Warszawa 1926, s. 47.

16 „Listy Harbińskie” 1932, nr 1, s. 6.

17 AAG, APP, sygn. 4, Raport Rady Organizacyjnej Polaków z Zagranicy, Warszawa 1932, k. 50. 
zamieścił, będący na miejscu, prezes Polskiej Izby Handlowej Wiktor Radwan, który był przekonany, iż w samym Harbinie znajdowało się około 1,5 tys. Polaków, zaś w całej Mandżurii nie mniej niż 3 tys. reprezentantów polskiej diaspory ${ }^{18}$. Wraz z pogarszającą się sytuacją materialną Polonii jej liczebność utrzymywała się na niskim poziomie. Większość naszych rodaków opuściła pomniejsze miejscowości na terenie Mandżurii i przeniosła się do Harbina. Stąd w latach 1935-1949 wielkość polskiego skupiska w Mandżurii, a więc głównie Harbinie, szacowano na przynajmniej 1,250 osób, chociaż liczba ta mogła być nieco zaniżona ${ }^{19}$.

Polonia mandżurska posiadała własne szkoły, konsulat, kościoły ${ }^{20}$, prasę, stowarzyszenia o charakterze kulturalnym i oświatowym, a nawet zakłady przemysłowe i koncesje na wydobycie ropy, złota czy węgla ${ }^{21}$. Ponadto Polakom, korzystającym ze sprzyjających warunków politycznych i odpowiedniego przygotowania zawodowego, udało się zająć eksponowane stanowiska w lokalnym przemyśle i gospodarce Mandżuriii22. Dodatkowo część z nich doskonale odnalazła się w bankowości, handlu, medycynie, sądownictwie ${ }^{23}$, a nawet samorządzie miejskim ${ }^{24}$.

18 „Echo z Dalekiego Wschodu” 1934, nr 3, s. 17.

19 A. Winiarz, Działalność Polskiego Komitetu Opiekuńczego w Harbinie (1942-1945), „Rocznik Polonijny" 1984-1985, s. 196.

20 J. SzYMaŃski, Opieka duszpasterska nad Polakami w Harbinie, „Studia Polonijne” 38(2017), s. $37-55$.

${ }^{21}$ M. Bonysiewicz, Przedsiębiorczość polska w Harbinie w latach 1898-1945, [w:] Polska i sąsiedzi na przestrzeni wieków. Prace doktorantów historii II. Na wojnie i w czasach pokoju, red. W. Skóra, A. Teterycz-Puzio, Słupsk 2018, s. 82-90.

${ }^{22}$ Historyczna Mandżuria to kraina o obszarze $1,3 \mathrm{mln} \mathrm{km}^{2}$, cztery razy większa od dzisiejszej Polski. W latach trzydziestych XX wieku zamieszkiwało ją ponad $30 \mathrm{mln}$ osób, w 1959 r. co najmniej 51 mln, w 1998 r. 100 mln, natomiast na początku XXI wieku niecałe 107 mln (M. EPsTeIN, The Statesman's Year-Book 1936, London 1936, s. 759; S. SteInBerg, The Statesman's Year-Book, London 1959, s. 889; B. HunTER, The Statesman's Year-Book 1998, London 1998, s. 349; B. TuRner, The Statesman's Year-Book 2007, New York 2007, s. 318). Teren ten posiada naturalne granice. Od północy tworzy je rzeka Amur, od wschodu rzeka Ussuri, od południowego wschodu rzeka Julu, stanowiąca granicę z Koreą, od południa Morze Żółte, od południowego zachodu Wielki Mur Chiński, od zachodu stepy Mongolii i od północnego zachodu rzeka Arguń. Środkowa równina Mandżurii, dzięki znakomitej glebie, stanowiła spichlerz wschodniej Azji (uprawiano tam ryż, soję, bawełnę, tytoń). Występują tu zasoby węgla, ropy naftowej, rudy, złota, a także olbrzymie zasoby energii wodnej. Chiński rozwój gospodarczy w dużym stopniu ma swoje korzenie w Mandżurii (W. Skóra, Placówki MSZ Drugiej Rzeczypospolitej w Harbinie w latach 1920-1941, s. 679).

${ }^{23}$ W. TheIss, Dzieci syberyjskie, s. 28.

${ }^{24}$ Autorem pierwszego planu Harbina był inż. Konstanty Jokisz, w 1908 r. zastępcą burmistrza miasta został inż. Eugeniusz Dynowski, który w latach 1910-1911 pełnił funkcję burmistrza. W tym samym czasie Rada Miejska Harbina była całkowicie zdominowana przez Polaków i Niemców (K. Grochowski, Polacy na Dalekim Wschodzie, Harbin 1928, s. 55; „Biuletyn Polskiej Izby Handlowej w Harbinie” 1932, nr 5, s. 3; „Listy Harbińskie” 1932, nr 5, s. 2). 
Niewątpliwie swobodny rozwój polskiej enklawy w Mandżurii wiązał się z działalnością polskiego konsulatu w Harbinie, który utworzono w marcu 1920 r. Do zadań tej placówki należało m.in. udzielanie pomocy finansowej i merytorycznej naszym rodakom. Bardzo szybko konsulat stał się centralnym punktem w życiu polskiej społeczności na terenie Mandżurii25.

Natomiast historia oficjalnych kontaktów między Polską a Japonią sięga marca 1919 r., kiedy Japonia formalnie uznała niepodległą Polskę ${ }^{26}$. Jednak nieoficjalne kontakty polsko-japońskie zaczęły się już w połowie XVII wieku ${ }^{27}$. Wówczas do Japonii dotarli pierwsi misjonarze. Jednym z nich był Wojciech Męciński (1598-1643), polski jezuita. Pod koniec czerwca 1636 r. polski misjonarz udał się do Makau, skąd próbował bezskutecznie przedostać się do Japonii. Holendrzy porwali okręt, którym płynął, i skierowali go na Formozę. W 1637 r. jezuita uciekł ze statku holenderskiego w czasie transportowania więźniów do Batawii. Ostatecznie 11 sierpnia 1642 r. udało mu się przybyć - w przebraniu Chińczyka - na Wyspy Japońskie, dokładnie na półwysep Satzuma, do twierdzy Kagoshima. Właśnie tam słudzy szoguna Hitetady schwytali go wraz z trzema towarzyszami, po czym przetransportowali do Nagasaki ${ }^{28}$. Po ponad dwustu dniach tortur Męcińskiego zawieszono na krzyżu głową w dół, po czym jego ciało spalono, a popioły wrzucono do morza ${ }^{29}$. Wieści o śmierci polskiego misjonarza dotarły do kraju w 1647 r., wywołując ogromne poruszenie. Jezuicki kaznodzieja Kasper Drużbicki opisał jego żywot i męczeńską śmierć za wiarę. Sami jezuici podjęli starania o wszczęcie procesu beatyfikacyjnego, który zakończył się w 1700 roku stwierdzeniem kanonicznie jego śmierci za wiarę i wpisaniem w poczet świątobliwych zakonników ${ }^{30}$.

${ }^{25}$ K. Symonolewicz, Miraże mandżurskie, s. 268.

${ }^{26}$ M. NowaK-Kielbikowa, Japan and China in Polish Diplomacy, 1918-1939 (An Attempted Outline), „Acta Poloniae Historica” 49(1984), s. 164.

27 Najprawdopodobniej po raz pierwszy Polacy usłyszeli o Japonii w XV wieku z łacińskich odpisów Opisania świata autorstwa Marco Polo, gdzie można było przeczytać o tajemniczym państwie Zipingu, czyli kraju wschodzącego słońca (M. Polo, Opisanie świata, Warszawa 1954, s. 396-397).

${ }^{28}$ Pod koniec XVI wieku możni japońscy zmienili stosunek do chrześcijan, czego skutkiem były liczne prześladowania i egzekucje wiernych. Bezpośrednią przyczyną były chłopskie bunty, w których dość znaczny udział brali wyznawcy Chrystusa. Już w 1597 r. ukrzyżowano 25 japońskich chrześcijan, lecz dopiero w 1622 r., po ukrzyżowaniu pierwszych europejskich misjonarzy, można mówić, że pobyt w Japonii stał się dla obcokrajowców niebezpieczny (W. PADACz, Z polskiej gleby, Kraków 1973, s. 446-461).

${ }^{29}$ B. NATOŃSKI, Wojciech Męciński, [w:] Gdy Europa szukała Azji, red. F. Plattner, Kraków 1975, s. 303-315.

${ }^{30}$ D. NGuYEn, Polscy misjonarze na Dalekim Wschodzie w XVII-XVIII wieku, Warszawa 2006, s. 64-69. 
Na szczęście kolejne związki Polski z Japonią nie były aż tak dramatyczne. Jednak prawdziwy rozkwit stosunków polsko-japońskich nastąpił dopiero w okresie II Rzeczypospolitej. Tym sposobem w 1922 r. w Warszawie powstało Towarzystwo Polsko-Japońskie dla promocji kultury polskiej w Japonii, którego pierwszym prezesem był hrabia Henryk Potocki ${ }^{31}$. W odpowiedzi w 1924 r. założono w Tokio Towarzystwo Japońsko-Polskie w celu nawiązania bliższych kontaktów naukowych, kulturalnych i ekonomicznych z polskim społeczeństwem. Na jego czele stał członek rodziny cesarskiej, książę Yasuhiko Asaka. Co więcej, w okresie międzywojennym dochodziło między oboma krajami do rozmaitych kontaktów na polu wojskowym, kulturalnym i naukowym ${ }^{32}$. W tym samym czasie w Warszawie została założona podobna organizacja, której celem było pogłębianie współpracy pomiędzy Polską i Chinami ${ }^{33}$. W 1934 r. założono też Towarzystwo Studiów nad Polską, a dwa lata później Japońsko-Polskie Towarzystwo Handlowe ${ }^{34}$. Z kolei we Lwowie powstało Towarzystwo Przyjaciół Dalekiego Wschodu, które dzieliło się na trzy sekcje, to jest chińską, japońską i sachalińską. Prezesem jego był znany literat i historyk Józef Białynia-Chłodecki ${ }^{35}$. W latach dwudziestych i trzydziestych kolonia polska w Japonii liczyła, oprócz urzędników Polskiego Poselstwa, a następnie Ambasady Rzeczypospolitej Polskiej, zaledwie kilkanaście osób. Nieliczne Polki były zazwyczaj żonami Polaków, którzy pracowali tam jako przedstawiciele handlowi firm krajowych i zagranicznych ${ }^{36}$.

Nie wolno pominąć faktu, iż niewielkie skupiska Polaków były obecne na terenie całego Dalekiego Wschodu ${ }^{37}$. Niemniej jednak najliczniejsze przejawy zainteresowania losem tamtejszych kobiet dotyczyły na ogół Japonii oraz Chin. Walka z niesprawiedliwością względem kobiet toczyła się w Chinach od setek lat, jednak ich położenie uległo względnej poprawie dopiero w pierwszych dekadach $\mathrm{XX}$ wieku ${ }^{38}$.

${ }^{31}$ R. ZajĄCZKowski, Literatur polska w Japonii, „Roczniki Kulturoznawcze” 7(2016), nr 3, s. 149.

32 W. KotańsKi, K. SEYFried, Stosunki kulturalne między Polska i Japonia, , Przegląd Orientalistyczny" 1961, nr 2, s. 141-156.

${ }^{33}$ Towarzystwo Polsko-Chińskie zostało założone pod koniec lat dwudziestych XX wieku przez Tadeusza Szukiewicza, działało na znacznie mniejszą skalę i nie cieszyło się wsparciem władz, w przeciwieństwie do organizacji polsko-japońskich (KPS, ZS, sygn. 3398, List Tadeusza Szukiewicza do Zarządu Towarzystwa Polsko-Chińskiego, Warszawa, 30 czerwca 1930 r., k. 198-199).

${ }^{34}$ T. Szubiakiewicz, Japonia-Polska coraz bliżej siebie, Warszawa 2002, s. 52.

${ }^{35}$ K. Grochowski, Polacy na Dalekim Wschodzie, s. 148.

${ }^{36}$ KPS, ZS, sygn. 3399, Polska działalność gospodarcza na Dalekim Wschodzie. Przeszłość i przyszłość organizacji wywozu, Tadeusz Szukiewicz, Kraków 1949, k. 157.

37 Por. K. Grochowski, Polacy na Dalekim Wschodzie, s. 108-178.

38 D. Ko, Women's History: Asia, [w:] Encyclopedia of Historians and Historical Writing, vol. 2 , ed. K. Boyd, London 1999, s. 1312-1315. 
Polscy autorzy zwracali szczególną uwagę na trzy podstawowe problemy kobiet w Chinach. Pierwszym było to, że w rodzinie ukształtowanej według konfucjańskich zasad kobieta od dziecka zajmowała podrzędną pozycję ${ }^{39}$. Od wczesnych lat matka przygotowywała ją do zamążpójścia, wpajając zasady dobrych manier i posłuszeństwa wobec mężczyzn, a także starszych ${ }^{40}$. Kobiety całą młodość spędzały w żeńskiej części ojcowskiego domu, gdy miały 12 lub 15 lat wydawano je za mąż, zazwyczaj nie pytając nikogo o zgodę ${ }^{41}$. Ich mężowie byli też najczęściej młodzi, średnio w wieku 18 albo 19 lat. Prócz żony mężczyzna miał nałożnice. Dzieci nałożnicy uważano za dzieci pierwszej żony. Znaczenie miała tylko ta żona, która wydała na świat męskiego potomka. Jeśli żona nie urodziła syna, mąż miał prawo

39 Warto w tym miejscu zwrócić uwagę na kwestię traktowania chłopców i dziewcząt w pierwszych dekadach XX wieku na terenie Chin. Tym bardziej że problem ten jest ciągle obecny w chińskim społeczeństwie i powoduje nierównowagę demograficzną pomiędzy kobietami a mężczyznami. Chodzi o to, że dzieci płci żeńskiej, zgodnie z prawem Konfucjusza, były uważane za nieużyteczny ciężar, który nie będzie nawet pomocny przy utrzymaniu rodu, ponieważ przez małżeństwo straci związek z rodziną, czyli rodem, z którego pochodzi. W rodzinach chińskich, a zwłaszcza w warstwach niezamożnych, bardziej wyczekiwano urodzenia tylko syna, który mógł być pomocnikiem w pracy, podporą i opiekunem w starości, oraz „przedłużycielem rodu i chronicielem mogił przodków”. Chęć posiadania wyłącznie męskiego potomka powodowała często, szczególnie w latach nieurodzaju i klęsk, tragiczny objaw sprzedaży dziewcząt do domów publicznych, a nawet ich zabijanie (Z. Kozıowski, Matżeństwo w Chinach, „Echo z Dalekiego Wschodu” 1939, nr 6, s. 12; AAG, APP, sygn. 65, Śmierć i pogrzeb pogański w Chinach Pólnocnych, s. Anna Szołdarska, Siostra Miłosierdzia, Catholic Mission, Shuntehfu, China [brak daty], k. 10-12). Dziewczynki, postrzegane jako istoty niższe, nie wzbudzały w sercach rodziców cieplejszych uczuć, ani głębszej troski o odpowiednią opiekę i wychowanie. Zjawisko to zostało opisane przez Emilię Czajewską na przykładzie rodziny jej chińskiego służącego, który nie przejmował się zbyt mocno śmiercią swojej kilkuletniej córki, podobnie zresztą jak jego żona (KPS, ZS, sygn. 3390, Wspomnienia z lat młodości w Harbinie (19211945) Emilii Czajewskiej, k. 13).

${ }^{40}$ K. Symonolewicz, Moi Chińczycy. 18 lat w Chinach, Warszawa 1938, s. 15-16; G. HerShatter, Z. WAng, Chinese History: A Useful Category of Gender Analysis, „American Historical Review" 113(2008), nr 5, s. 1404-1421.

${ }^{41}$ Idealna chińska małżonka nie musiała być inteligentna, mądra czy ładna. Ważne, aby była uprzejma, łagodna, spokojna, czysta i staranna. Sposób myślenia Chinek był tak ukształtowany, iż one same uważały, że są przeznaczone przede wszystkim do dźwigania ciężarów życia domowego i posłuszeństwa mężczyźnie. Ich mentalność wyrażała się w przeświadczeniu, że cnotą każdej kobiety jest nie być zbyt inteligentną. Dzięki temu w początkach XX wieku duża część nawet wysoko urodzonych kobiet w Chinach nie posiadała umiejętności czytania i pisania. Zachowanie mężczyzn dodatkowo sprzyjało kształtowaniu typu pokornej, służebnej i odpornej na trudy życia córki, żony oraz matki (A. Hansson, Chinese Outcasts: Discrimination and Emancipation in Late Imperial China, New York 1996, s. 45-46; R.R. WANG, Images of Women in Chinese Thought and Culture: Writings from the Pre-Qin Period Through the Song Dynasty, Cambridge 2003, s. 414-417; R. TANnahILl, Historia seksu, Warszawa 2001, s. 193). 
rozwieść się z nią. Natomiast kobiety nie miały takiego prawa ${ }^{42}$. Co więcej, jeśli mąż przyłapał żonę na zdradzie, miał prawo ją zabić bez jakichkolwiek konsekwencji. To samo dotyczyło się jej kochanka ${ }^{43}$.

Drugim problemem było kaleczenie nóg u młodych dziewczynek, co nie dotyczyło jednak Mandżurów ${ }^{44}$. W Chinach uważano, że powabu dodają kobietom bardzo małe stopy. Zwyczaj bandażowania stóp siedmioletnich dziewcząt w celu powstrzymania wzrostu stopy zapoczątkowany został około 970 r. n.e. ${ }^{45}$ Stopa była uważana za najbardziej wstydliwą część ciała kobiety. W towarzystwie nie wypadało mówić o stopie kobiety, a spoglądanie na nogi kobiet traktowane było jako

${ }^{42}$ AAG, APP, sygn. 65, Zaślubiny w Chinach, s. Anna Szołdarska, Siostra Miłosierdzia, Catholic Mission, Shuntehfu, China [brak daty], k. 7-9; S. WANG, The 'New Social History' in China: The Development of Women's History, „The History Teacher” 39(2006), nr 3, s. 315-320.

${ }^{43}$ Konfucjusz ustanowił różne zasady moralne dla kobiet i mężczyzn. Kobiecie nakazał czystość i obowiązek jako cnotę oraz podporządkowanie się mężczyźnie, którego przykazania te nie dotyczyły Konfucjański paternalizm zobowiązywał kobietę do wierności mężowi. W praktyce małżonki traktowały takie nakazy w swobodny sposób. Jeśli jednak mąż schwytał żonę z kochankiem, mógł go zabić lub też kochanek dawał okup, a mąż albo darował żonie winę, albo sprzedawał ją do domu publicznego. Czasami, po osądzeniu wiarołomnej pary przez starszyznę, wiązano kochanka z niewierną żoną i topiono (K. ImIELIŃSKI, Sekrety seksu, Warszawa 1990, s. 90-91).

${ }^{44}$ Od końca XIX do połowy XX wieku toczyła się zacięta rywalizacja pomiędzy Rosją (później ZSRR) a Japonią o panowanie nad Mandżurią, chociaż ta wciąż formalnie należała do Chin. Początkowo znaczną przewagę udało się zdobyć Rosjanom, którzy opanowali północną część Mandżurii, z której wywodziła się ówcześnie panująca w Chinach dynastia Qing. Pomimo tego obszar ten w zdecydowanej większości zamieszkiwali Chińczycy z południa kraju. Z kolei autochtoniczne plemiona mandżurskie ulegały stopniowej asymilacji z ludnością chińską przynajmniej od drugiej połowy XIX wieku, gdy lokalne elity dobrowolnie forsowały naukę języka mandaryńskiego, a więc standardowego języka chińskiego (Manchuria as a demographic frontier, „Population Index” 11(1945), nr 4, s. 261-262; S.M. Shirokogorov, Social organization of the Manchus. A study of the Manchu clan organization, New York 1924, s. 3-4). Tym samym w latach trzydziestych XX wieku plemiona mandżurskie niemal przestały już istnieć. W połowie lat trzydziestych XX wieku ich liczebność szacowano na około 200 tys. osób, które rzekomo nie miały własnej odrębności etnicznej i przeważnie używały języka chińskiego (E.J. Reyman, Encyklopedia, t. III, s. 867). Jedyną liczącą się mniejszością, która nie przyjęła chińskich zwyczajów, byli Mongołowie, zamieszkujący zachodnie obszary północno-wschodnich Chin (O. LatTimore, The Mongols of Manchuria, New York 1934, s. 97). Trudno przedstawić wiarygodne dane dotyczące ich liczebności w Mandżurii. Japończycy, próbując osłabić pozycję strony chińskiej i pozyskać sympatię ludności mongolskiej, sugerowali obecność prawie $2 \mathrm{mln}$ Mongołów, co m.in. miało uzasadnić oderwanie Mandżurii od Chin w 1932 r. (A.J. GraJdAnzev, The Mongols of Manchuria. Their tribal divisions, geographical distribution, historical relations with Manchus and Chinese, and present political problems, „Pacific Affairs” 8(1935), nr 3, s. 368-369). W rzeczywistości społeczność mongolska w pierwszych dekadach XX wieku najprawdopodobniej nie przekraczała liczby 500 tys. osób (L. TANG, China facts and fancies, Shanghai 1936, s. 85).

45 „China Monthly Review” 8(1919), s. 492. 
zachowanie skandaliczne ${ }^{46}$. Rozczarowanie narzeczonego wielkością stopy narzeczonej stanowiło wystarczający powód do anulowania obietnicy małżeństwa ${ }^{47}$. Obyczaj ten zniknął dopiero wraz z cesarstwem i całym konfucjańskim systemem wartości ${ }^{48}$, co nastąpiło w 1912 r. po abdykacji ostatniego cesarza Chin Puyi ${ }^{49}$, oraz dzięki staraniom licznych stowarzyszeń kobiecych zarówno chińskich, jak i europejskich ${ }^{50}$. Pomimo tego jeszcze $\mathrm{w}$ drugiej połowie XX wieku organizowano w Chinach konkursy piękności stopy ${ }^{51}$.

Ostatnim problemem była prostytucja, którą określano mianem plagi społecznej. Prostytucja w Chinach wiązała się głównie z niskim poziomem życia

${ }^{46}$ K. Imieliński, Seksuologia. Mitologia. Historia. Kultura, Warszawa 1989, s. 195; Z. WróBeL, Dzieje erotyzmu, t. III: Uczta trzech szczytów. Chińskie obyczaje erotyczne, Bydgoszcz 2000, s. 37-38.

47 „The Spectator” 80(1898), s. 407.

${ }^{48}$ Konfucjanizm był systemem filozoficzno-religijnym zapoczątkowanym w Chinach przez Konfucjusza (551-479 p.n.e.) w V wieku p.n.e. Następnie nurt ten rozwijali kolejni chińscy mędrcy, w tym Mencjusz (371-289 p.n.e.) oraz Xunzi (298-238 p.n.e.) w III wieku p.n.e. Konfucjanizm głosił, iż zbudowanie idealnego społeczeństwa i osiągnięcie pokoju na świecie jest możliwe pod warunkiem przestrzegania obowiązków wynikających z hierarchii społecznej oraz zachowywania tradycji, czystości, ładu i porządku. Konfucjanizm rozpowszechnił się nie tylko w Chinach, lecz także w Korei, Wietnamie i Japonii, stając się dominującą doktryną państwowo-religijną na tych obszarach, kształtując ich politykę oraz obyczaje nawet w czasach współczesnych (X. YAO, An Introduction to Confucianism, Cambridge 2000, s. 38-47). Według konfucjańskiego systemu zasad i wartości kobiety podlegały dyskryminacji, zajmując podrzędne miejsce w społeczeństwie w stosunku do mężczyzn. Za podstawę struktury idealnego państwa Konfucjusz uważał tradycyjną chińską rodzinę, która składała się z głowy rodu i następnie hierarchicznie podporządkowanych mu potomków. W rodzinie takiej głowa rodu miała absolutną władzę. Natomiast kobiety zawsze musiały podporządkowywać się woli męża, nawet jeśli sądziły, że ten błądzi lub nie ma racji (P.B. EBrey, Women and the Family in Chinese History, London 2002, s. 10-12; X. GAO, Women Existing for Men: Confucianism and Social Injustice against Women in China, „Race, Gender and Class" 3(2003), s. 114-120; L.L. RosenLeE, Confucianism and Women. A Philosophical Interpretation, Albany 2006, s. 15-16).

49 J. FenBy, Chiny. Upadek i narodziny wielkiej potęgi, Kraków 2009, s. 948.

${ }^{50}$ Największe stowarzyszenie, o nazwie Anti-Foot-Binding Society, domagające się zaprzestania tego procederu powstało w Szanghaju już w 1898 r. Skupiało w swoich szeregach zarówno Chinki, jak i Europejki. Wkrótce udało im się rozszerzyć swoją działalność na inne miasta Państwa Środka („Chinese Recorder” 29(1898), s. 579).

${ }^{51}$ Ze względu na to, że krępowanie okaleczało kobiety i niosło wiele cierpienia, obyczaj ten był krytykowany, szczególnie intensywnie na początku XX wieku. Po powstaniu Republiki Chińskiej w 1912 r. tego rodzaju zabiegi zostały zakazane. Natomiast w następstwie utworzenia Chińskiej Republiki Ludowej w 1949 r. całkowicie je wypleniono. W Chinach wymarło już niemal całkowicie ostatnie pokolenie kobiet, które poddawano krępowaniu stóp (L. Yutang, My Country and My People, New York 1935, s. 164-166; W.J. Sidichmienow, Chiny. Karty przeszłości, Warszawa 1978, s. 215-217). 
i ciągłymi wojnami domowymi ${ }^{52}$. Często młode dziewczyny już w wieku 13 lat były sprzedawane do domów publicznych przez swoich rodziców. Proceder ten, podobnie jak prostytucja, nie był nielegalny ${ }^{53}$. Właścicielki „błękitnych domów”, ponieważ najczęściej były nimi kobiety, mogły zrobić wszystko ze swoimi ofiarami. Wyjątek stanowiły dziewczęta przeznaczone na eleganckie kurtyzany, które uczono czytać i pisaćs4. Niektóre z nich miały szczęście i mogły się wykupić, niekiedy udawało im się wyjść za mąż i uniknąć przykrych konsekwencji swojej pracy, które najczęściej wiązały się z szeroko rozpowszechnionymi chorobami wenerycznymi ${ }^{55}$.

W 1891 r. Kang Youwei (1858-1927), przywódca stronnictwa reformatorów ${ }^{56}$, dał początek chińskiemu feminizmowi, żądając zrównania pozycji społecznej kobiet i mężczyzn, w tym praw wyborczych ${ }^{57}$. Jego żądania nie zostały spełnione,

${ }^{52}$ Bezspornie Chiny, pomimo rewolucji z 1911 r. i obalenia bezsilnej monarchii, nadal pogrążone były w chaosie politycznym. Tym sposobem na terenie Chin do 1949 r. trwała chroniczna wojna domowa połączona z bezwzględnym najazdem armii japońskiej na zachodnie regiony kraju. Konflikt ten pochłonął dziesiątki milionów ofiar i zniszczył ogromne połacie państwa, skutecznie blokując procesy modernizacji. W następstwie tego chaosu wyłoniły się Chiny pod przewodnictwem Mao Zedonga (W. Skóra, Placówki MSZ Drugiej Rzeczypospolitej w Harbinie w latach 1920-1941, s. 680). W latach 1898-1949, pomimo wyniszczających konfliktów zbrojnych, liczba ludności w Chinach systematycznie rosła od 350 do $457 \mathrm{mln}$ osób (J. Scotт-Keltie, The Statesman's Year-Book, London 1885, s. 753; W. YUST, Britannica Book of the Year 1944, London 1944, s. 75). Poza tym epidemie głodu w latach 1921-1922, wywołane zbiorami płodów rolnych i suszą, zebrały żniwo w wysokości od 4 do 6 mln ofiar (Peking United International Famine Relief Committee, The North China Famine of 1920-1921, Peking 1922, s. 11-13). Dodatkowo bandytyzm stał się istotną zmorą. Część gangów stanowiły małe, lokalne grupy włóczęgów. Inne miały charakter mniej prowizoryczny, a na ich czele stali niekiedy byli wojskowi lub synowie nieźle sytuowanych rolników, którzy odczuli brak perspektyw i obrócili się przeciw społeczeństwu. Pośród hersztów łupieżczych zagonów trafiały się także kobiety. Jako przykład może posłużyć działająca w południowym Shandongu Mama Chao, która skupiła pod swoimi rozkazami około 700 kobiet, czy też wojująca w Anhui zabójczyni o przydomku Chang Dwie Spluwy, ruszająca do boju z pistoletem w każdej dłoni (E.J. Perry, Rebels and Revolutionaries in North China, 1845-1945, Stanford 1980, s. 71; TENŻE, Challenging the Mandate of Heaven. Social Protest and State Power in China, Armonk 2002, s. 17). W takich warunkach walka o prawa kobiet i poszanowanie ich godności schodziły na dalszy plan.

53 S. Mann, Precious Records: Women in China's Long Eighteenth Century, Stanford 1997, s. 26.

${ }^{54}$ B. HINsch, Women in Imperial China, Lanham 2016, s. 176-177.

${ }_{55}$ F. Arkin, Kobieta Dalekiego Wschodu, s. 9.

56 Imagining the People: Chinese Intellectuals and the Concept of Citizenship, 1890-1920, eds. J.A. Fogel, P.G. Zarrow, London 1997, s. 69; The Birth of Chinese Feminism: Essential Texts in Transnational Theory, eds. L.H. Liu, R.E. Karl, D. Ko, New York 2013, s. 6-7.

${ }^{57}$ Kang Youwei pochodził z rodziny szlacheckiej, od wczesnej młodości buntował się przeciwko urządzonemu według zasad konfucjanizmu modelowi społecznemu obowiązującemu w cesarskich 
jednak po utworzeniu republiki w 1912 r. i zmianach w Konstytucji Prowizorycznej z dnia 1 maja $1914 \mathrm{r}$. w chińskim prawie rodzinnym nastąpił pewien zwrot $^{58}$. Na pierwszy plan wysuwało się szczęście osobiste, zachowanie zaś ciągłości rodu miało znaczenie drugorzędne. Kwestia rozwodu miała rozstrzygać się bilateralnie według nowoczesnych zapatrywań ${ }^{59}$. Stopniowo, przynajmniej formalnie, zanikała władza męża nad żoną. W kolejnych latach kobiety zyskały możliwość kształcenia. Powstały szkoły podstawowe, średnie i wyższe, gdzie dziewczynki uczyły się razem z chłopcami. Kobiety zyskały dostęp do wielu zawodów. Pracowały m.in. jako lekarki, wykładowczynie na uniwersytetach i nauczycielki ${ }^{60}$, odgrywając coraz większą rolę w życiu ekonomicznym i politycznym Chin. Już w 1911 r., podczas rewolucji, organizowano oddziały kobiece, które walczyły pod Nankinem i Szanghajem. Jednak głównym postulatem stawianym przez rzesze Chinek i Japonek było przyznanie kobietom praw wyborczych. W przypadku Chin było to możliwe dopiero w $1947 \mathrm{r}^{6}{ }^{61}$

Chinach. Inspirował się głównie filozofią buddyjską, głosił potrzebę sprawiedliwości społecznej, uwzględniającej prawa kobiet. Nawoływał do głębokich reform, które miały uratować Chiny przed upadkiem. W 1883 r. opowiedział się przeciwko krępowaniu stóp dziewczynkom, a pięć lat później wystosował memoriał do cesarza, który nie trafił do rąk monarchy (E. KAJDAŃsKi, Chiny. Leksykon. Historia, gospodarka, kultura, Warszawa 2005, s. 107-108). W roku 1891 Kang Youwei opublikował studium Badanie klasycznych ksiag sfałszowanych w epoce Xin. Uważał, że klasyczne księgi czczone i objaśniane przez chińskich uczonych są w większości sfałszowane, a tym samym nie pochodzą od Konfucjusza. Był również jednym z głównych doradców cesarza Guangxu (1871-1908), który pomiędzy 11 czerwca a 21 września 1898 r. wydał prawie 40 dekretów reformatorskich, mających na celu modernizację Chin. Reformy zostały jednak storpedowane przez konserwatywne kręgi dworskie, a 21 września 1898 r. doszło do zamachu stanu, w wyniku którego Guangxu został internowany w Pałacu Letnim. Jednocześnie wszystkie dekrety cesarskie anulowano. Kang Youwei zdołał uciec do Japonii, a następnie udał się do Stanów Zjednoczonych i Kanady, gdzie w 1899 r. założył Stowarzyszenie Obrony Cesarza, domagające się wprowadzenia w Chinach monarchii konstytucyjnej (J. PoLIT, Chiny, Warszawa 2004, s. 52). Po upadku cesarstwa powrócił w 1914 r. do Chin. Jego wpływy znacząco osłabły, ale w 1917 r. zdołał jeszcze poprzeć dokonaną przez generała Zhang Xuna (18541923) próbę restauracji monarchii (J.K. FaIRBank, Historia Chin. Nowe spojrzenie, Gdańsk 1996, s. 208-210; Confucian Personalities, eds. A.F. Wright, D. Twitchett, Stanford 1962, s. 294-316).

${ }^{58}$ F. Arkin, Kobieta Dalekiego Wschodu, s. 8; J. Polit, Chiny, Warszawa 2004, s. 351.

59 Z. Kozıowski, Matżeństwo w Chinach, s. 11-12. Rozwiązania prawne dotyczące rozwodów zostały przyjęte przez władze chińskie w maju 1950 r. (E. JEFFreys, Sex and Sexuality in China, London 2006, s. 62-65).

${ }^{60}$ R. Thakur, Women's Studies in China Today, „Economic and Political Weekly” 41(2006), nr 42, s. 4455; W.Y. LeE, Women's Education in Traditional and Modern China, „Women's History Review" 4(1995), nr 3, s. 345-360.

${ }^{61}$ Chinki uzyskały prawa wyborcze w 1947 r. wraz z uchwaleniem konstytucji Republiki Chińskiej, której udało się przetrwać w latach 1912-1949 (L. EDwARDS, Women's Suffrage in China: Challenging Scholarly Conventions, „Pacific Historical Review” 69(2000), nr 4, s. 617). 
Natomiast Japonki uzyskały prawa wyborcze nieco wcześniej, to znaczy w 1946 r. ${ }^{62}$, aczkolwiek droga prowadząca do tego osiągnięcia nie była prosta ${ }^{63}$. W 1900 r. rząd zabronił kobietom przynależności do partii politycznych i udziału w wiecach partyjnych. Niemniej jednak Japonki nie zaprzestały starań o równouprawnienie, kładąc tym razem nacisk na konieczność przestrzegania monogamii przez mężczyzn, która w praktyce nie istniała. Ruch feministyczny pojawił się w Japonii pod koniec XIX wieku ${ }^{64}$. Głównym bodźcem do usamodzielnienia się Japonek stały się liczne przekłady z literatury europejskiej z tego okresu ${ }^{65}$. Jednak początkowo feminizm nie odgrywał ważnej roli. Od 1903 r. ruch ten zyskał wybitnie socjalistyczny charakter ${ }^{66}$. Mimo wszystko w pierwszych dekadach XX wieku bardzo dużą rolę odgrywała tradycja, z czego wynikało bezwzględne posłuszeństwo względem męża. Co więcej, podobnie jak w Chinach, małżeństwo zawierano

${ }^{62}$ K. KarolczaK, System konstytucyjny Japonii, Warszawa 1999, s. 23. Na uwagę zasługuje fakt, że w 1947 r. znowelizowano japoński kodeks cywilny, m.in. zrównując małżonków w wykonywaniu władzy rodzicielskiej i umożliwiając kobiecie sprawowanie jej po rozwodzie (A. Kość, Filozoficzne podstawy prawa japońskiego w perspektywie historycznej, Lublin 2001, s. 112).

${ }^{63}$ Jakkolwiek postępująca emancypacja kobiet przeciwstawiała się ich jawnej dyskryminacji, tempo zachodzących zmian uległo przyśpieszeniu dopiero w następstwie klęski militarnej Japonii w 1945 r. Amerykańskie władze okupacyjne, chcąc przekształcić Japonię w pokojowo usposobioną demokrację, opracowały projekt nowej konstytucji, który w miejsce przedwojennej retoryki wielkości cesarza i gorliwości poddanych wprowadzał język pokoju, wolności i demokracji. Dokument ten pozbawił cesarza majątku prywatnego i ograniczył zakres jego władzy do funkcji ceremonialno-reprezentacyjnych. Podporządkował gabinet wyłanianemu w wyborach powszechnych dwuizbowemu parlamentowi oraz zlikwidował arystokrację, pozbawiając około 900 rodzin tytułów. Przyznał prawo wyborcze kobietom, a także poszerzył ich prawa małżeńskie. Wzmocnił szeroki zakres swobód obywatelskich i uznał prawo robotników do zrzeszania się. Oddzielił władzę sądowniczą od organów administracji rządowej, ograniczył uprawnienia policji, a w ogólnym wymiarze dążył do zwiększenia społecznej kontroli rządu (C. Totman, Historia Japonii, Kraków 2009, s. 588; K. G. Henshall, Historia Japonii, Warszawa 2011, s. 170). Jednak dopiero w 1976 r. po raz pierwszy kobieta weszła w randze ministra w skład stałej misji w Organizacji Narodów Zjednoczonych, zaś w 1980 r. pierwsza Japonka objęła funkcję ambasadora (J. RuBACH-KuCZEwska, Życie po japońsku, Warszawa 1985, s. 129). Co więcej, w 1993 r., równolegle z utworzeniem rządu, w składzie którego znalazły się trzy kobiety, po raz pierwszy w historii Japonii kobieta przyjęła godność przewodniczącej Izby Reprezentantów (Leksykon państw świata 1994/1995, oprac. zespół pod kier. M.B. Michalika, Warszawa 1994, s. 219). W tym samym czasie nadal tylko $10 \%$ wszystkich stanowisk kierowniczych zajmowały kobiety (J.R. RENSHAW, Kimono in the Boardroom. The Invisible Evolution of Japanese Women Managers, New York 1999, s. 7).

${ }^{64}$ P. Reich, A. Fukuda, Japan's Literary Feminists: The “Seito” Group, „Signs” 2(1976), s. $280-289$.

${ }^{65}$ Wspótczesna kobieta japońska, „Echo z Dalekiego Wschodu” 1939, nr 2, s. 9.

${ }^{66}$ Y. NuITA, Fusae Ichikawa: Japanese Women Suffragist, „Frontiers: A Journal of Women Studies" 3(1978), nr 3, s. 58-62. 
bardzo wcześnie, kobiety najczęściej liczyły od 15 do 17 lat, a mężczyźni najczęściej byli w wieku 18 lub 19 lat ${ }^{67}$.

Położenie kobiety, jako żony, było zazwyczaj bardzo ciężkie. Mężatka, która opuściła męża, na zawsze okrywała się hańbą ${ }^{68}$. Z kolei mąż miał prawo mieć dowolną liczbę nałożnic. Pierwsza żona musiała być zawsze dobra dla ich dzieci. Aby otrzymać rozwód, do czego prawo miał tylko mężczyzna, wymagana była jedna z siedmiu następujących przyczyn: bezpłodność lub brak syna, niewierność małżeńska, brak posłuszeństwa względem teścia albo teściowej, gadatliwość, skłonność do kradzieży, zazdrość i choroby dziedziczne ${ }^{69}$. Po zamążpójściu kobieta musiała szanować rodzinę swojego męża bardziej niż własną. Tym sposobem nie naruszano jedności rodziny, uległości starszym i szacunku dla przodków. W latach trzydziestych XX wieku kobiety uzyskały prawo do rozwodów. Jednak, jak wynika ze statystyk z 1938 r., korzystały z niego niezwykle rzadko, co przedstawia tabela 1.

Tabela 1. Porównanie warunków życia kobiet w Japonii i innych państwach w 1938 r.

\begin{tabular}{|c|c|c|c|c|c|c|c|}
\hline \multirow{2}{*}{\multicolumn{2}{|c|}{ Treść }} & \multicolumn{6}{|c|}{ Kobiety } \\
\hline & & Francji & Anglii & Polski & Japonii & Ameryk & Niemiec \\
\hline \multicolumn{2}{|l|}{ Wychodzą za mąż } & $57 / 100$ & $52 / 100$ & $60 / 100$ & $62 / 100$ & $61 / 100$ & $55 / 100$ \\
\hline \multicolumn{2}{|l|}{ Rozwodza się } & $1 / 30$ & $1 / 80$ & $1 / 550$ & $1 / 1300$ & $1 / 8$ & $1 / 200$ \\
\hline \multicolumn{2}{|l|}{ Pracuja } & $37 / 100$ & $30 / 100$ & $36 / 100$ & $35 / 100$ & $22 / 100$ & $35 / 100$ \\
\hline \multicolumn{2}{|l|}{ Żyja średnio lat } & $47 \frac{1}{3}$ & $49^{3} / 4$ & $49^{1 / 3}$ & $42 \frac{1}{12}$ & $485 / 12$ & $492 / 3$ \\
\hline \multirow[t]{4}{*}{ Spożywają w ciągu roku } & chleba $(\mathrm{kg})$ & 134 & 158 & 132 & nie & 155 & 130 \\
\hline & mięsa $(\mathrm{kg})$ & 43 & 55 & 21 & 25 & 54 & 34 \\
\hline & wina (litr) & 176 & 1.3 & nie & nie & 30 & 16 \\
\hline & cukru $(\mathrm{kg})$ & 24 & 49 & 10 & 24 & 45.5 & 19.1 \\
\hline \multicolumn{2}{|c|}{ Rodzą dzieci rocznie (tys.) } & 630 & 600 & 950 & 2190 & 2150 & 1279 \\
\hline \multicolumn{2}{|c|}{ Małżeństw zawartych rocznie (tys.) } & 280 & 350 & 270 & 550 & 1800 & 600 \\
\hline \multicolumn{2}{|c|}{ Miernik pragnienia posiadania dziecka } & 2.0 & 1.71 & 3.51 & 4.0 & 1.19 & 2.13 \\
\hline \multicolumn{2}{|c|}{ Pala tytoń rocznie $(\mathrm{kg})$} & 1.3 & 1.5 & 0.5 & nie & 2.5 & 1.7 \\
\hline
\end{tabular}

Źródło: I. Godska, Kobieta w cyfrach, „Echo z Dalekiego Wschodu” 1938, nr 6, s. 22.

Jednym z głównych powodów usamodzielnienia się kobiet w Japonii było wielkie trzęsienie ziemi z września 1923 r. ${ }^{70}$ Japonki, które dotąd opierały swoją eg-

${ }^{67}$ F. Arkin, Kobieta Dalekiego Wschodu, „Daleki Wschód” 1934, nr 9-12, s. 9.

${ }^{68}$ A. Gordon, A Modern History of Japan: From Tokugawa Times to the Present: Tokugawa Times to the Present, London 2013, s. 152.

${ }^{69}$ Ciekawą ilustrację tego stanu rzeczy mogą stanowić losy tytułowej bohaterki melodramatu Namiko, kobiety pięknej i wrażliwej, głęboko kochającej swego męża Takeo, która zostaje zmuszona przez swoją rodzinę do rozwodu po tym, jak wychodzi na jaw, że cierpi ona na suchoty (K. TuкотомI, Namiko, tłum. J. Marlicz, Poznań 1924).

70 Trzęsienie ziemi miało miejsce w regionie Kantō na japońskiej głównej wyspie Honsiu w dniu 1 września 1923 r. Spowodowało śmierć blisko 142 tys. osób. Szacuje się, że straty przekroczyły 
zystencję na zarobkach ojca lub męża, wówczas w ciężkich warunkach, zmuszone zostały do myślenia o sobie i zaczęły garnąc się do wykonywania różnego rodzaju rzemiosła $^{71}$, a także zawodów ${ }^{72}$. Niewątpliwym sukcesem japońskiego feminizmu było założenie przez rząd Wyższej Szkoły Technicznej dla kobiet. Poza tym w latach dwudziestych i trzydziestych XX wieku liczne szkoły żeńskie, średnie oraz wyższe, najczęściej o profilu normalnym lub handlowym wydawały rok rocznie zastępy inteligentnych absolwentek ${ }^{73}$.

Również i nauka japońska, dzięki powstaniu takich instytucji, jak Japoński Uniwersytet dla Kobiet, Tokijska Żeńska Szkoła Języka Angielskiego oraz Tokijskie Żeńskie Kolegium Medyczne i Dentystyczne, wzbogaciła się o liczne grono kobiet, które przyczyniły się do podniesienia poziomu intelektualnego ogółu ${ }^{74}$. Warto przywołać w tym miejscu postać dr Kono Yasui (1880-1971) ${ }^{75}$, która po raz pierwszy

1 mld ówczesnych dolarów amerykańskich. Silny tajfun na wybrzeżu półwyspu Noto w prefekturze Ishikawa przyniósł wiatr w kierunku Zatoki Tokijskiej mniej więcej w tym samym czasie, co trzęsienie ziemi. Wiatry te spowodowały szybkie rozprzestrzenianie się pożarów towarzyszących trzęsieniu ziemi. Dodatkowo wiele domów zostało zasypanych obsunięciami zboczy górskich w zachodniej części prefektury Kanagawa. Na domiar złego fala tsunami o wysokości około 10 metrów uderzyła w wybrzeża zatoki Sagami, w półwyspy Bōsō, Izu, a także wyspy Izu. Ponad 570 tys. domów zostało zniszczonych, pozostawiając prawie $2 \mathrm{mln}$ osób bez dachu nad głową (C. DAVISON, The Japanese Earthquake of 1923, London 1931, s. 20-39; J.C. SCHENCKING, The Great Kanto Earthquake and the Culture of Catastrophe and Reconstruction in 1920s Japan, „Journal of Japanese Studies” 2(2008), nr 34, s. 295-331; E. LeE, The Great Kantō Earthquake and "Life-rationalization" by modern Japanese women, „Asian Journal of Women's Studies” 21(2015), nr 1, s. 2-18).

${ }^{71}$ Praca zarobkowa, czyli zatrudnienie przynoszące dochód, pod każdą szerokością geograficzną stanowi kwestię zarówno konieczności, jak i wyboru. Niemniej - co Tsuda Umeko (1864-1929), jedna z pierwszych propagatorek edukacji wśród Japonek, zauważyła już w 1915 r. - jest także kluczem do niezależności ekonomicznej, a więc do możliwości dokonywania wyborów w innych dziedzinach życia. Kiedy jednak praca zarobkowa została oddzielona od życia domowego, to do pracy zaczęli uczęszczać przede wszystkim mężczyźni, w ten sposób otwierając przed sobą nowe możliwości, podczas gdy kobiety zostawały w domu i były na ich utrzymaniu. W 1899 r. zszokowano japońską opinię publiczną udostępniając kobietom posady telefonistek, a na początku 1903 r. bileterek w kasach kolejowych (L. FréDÉRIC, Życie codzienne w Japonii u progu nowoczesności (1868-1912), Warszawa 1988, s. 138; Japan Encyclopedia, eds. L.F. Nussbaum, K. Roth, London 2002, s. 998).

72 B. Molony, Women's Rights, Feminism, and Suffrage in Japan, 1870-1925, „The Pacific Historical Review" 69(2000), nr 4, s. 657-661.

${ }^{73}$ Kobietom w Japonii zezwolono na naukę w szkołach podstawowych już w 1872 r. (L. FRÉDÉRIC, Życie codzienne w Japonii, s. 136).

${ }^{74}$ United States War Department, Civil Affairs Handbook, Japan, Prefectural Studies, Washington 1945, s. 235; „Official Gazette. English Edition” 1948, t. 526, s. 39; R. HiratsuKA, In the Beginning, Woman was the Sun: The Autobiography of a Japanese Feminist, New York 2006, s. 36-43.

${ }^{75}$ C.M.C. HaInes, International Women in Science: A Biographical Dictionary to 1950, Santa Barbara 2001, s. 339. 
w dziejach Japonii otrzymała tytuł profesorski w dziedzinie biologii na początku 1927 r., a następnie wykładała na wielu tokijskich uczelniach ${ }^{76}$. Największy jednak procent kobiet $\mathrm{z}$ inteligencji spotkać można było w zawodzie nauczycielskim ${ }^{77}$.

W związku z różnorodną pracą podejmowaną przez kobiety, powstały w Japonii rozmaite stowarzyszenia, m.in. Stowarzyszenie Pracownic Biurowych czy też Towarzystwo Kobiety Pracującej. Wspomniane stowarzyszenia starały się dbać o prawa kobiet w ich miejscach pracy, nawet jeśli przyszło im działać bez formalnego wsparcia związków zawodowych ${ }^{78}$. O dużej samodzielności Japonek w latach trzydziestych XX wieku świadczyło to, że wiele z nich prowadziło interesy handlowe, nawet na wielką skalę. Niektóre z nich zajmowały też stanowiska kierowniczek albo administratorek szkół. W dziedzinie muzyki, która dotychczas była opanowana przez mężczyzn, coraz śmielej do głosu dochodziły kobiety, na przykład Chieko Hara i Niwako Kai, uczestniczki konkursu chopinowskiego w Warszawie ${ }^{79}$. Droga do równouprawnienia kobiet Dalekiego Wschodu nie była łatwa, o czym pisały również przedstawicielki polskiej społeczności na Dalekim Wschodzie, niemniej jednak większość postulatów z pierwszej połowy XX wieku udało się obecnie spełnić.

\section{BIBLIOGRAFIA}

\section{Źródla archiwalne}

Archiwum Akt Nowych w Warszawie. Kolonia Polska w Mandżurii, sygn. 66, Historia kolonii polskiej w Mandżurii, oprac. K. Krąkowski, k. 7.

Archiwum Archidiecezjalne w Gnieźnie. Archiwum Prymasa Polski, sygn. 65, Zaślubiny w Chinach, s. Anna Szołdarska, Siostra Miłosierdzia, Catholic Mission, Shuntehfu, China [brak daty], k. 7-9.

Archiwum Państwowe w Szczecinie. Wojewódzki Oddział Państwowego Urzędu Repatriacyjnego w Szczecinie, sygn. 53, Sprawozdanie z przybyłych dwóch transportów z reemigrantami z Mandżurii na Punkt Etapowy nr 1 P.U.R. Szczecin i wyszczególnienie miejsca osiedlenia i pracy, Szczecin, 22 sierpnia 1949 r., k. 13-16.

Książnica Pomorska w Szczecinie. Zbiory specjalne, sygn. 3390, Wspomnienia z lat młodości w Harbinie (1921-1945) Emilii Czajewskiej, oprac., ilustracjami, dokumentami i komentarzem opatrzył J. Czajewski, Szczecin 1985, k. 1-5.

Książnica Pomorska w Szczecinie. Zbiory specjalne, sygn. 3399, Polska wyspa na Żółtym Morzu, Tadeusz Szukiewicz, Kraków, 28 listopad 1949, k. 178-179.

76 „The Modern Review” 1928, t. 44, s. 458.

77 Japan. Department of Education, Annual Report of the Minister of State for Education, 1935, Tokyo 1935, s. 122-123; Japan. Department of Education, Annual Report of the Minister of State for Education, 1937, Tokyo 1937, s. 130.

${ }^{78}$ Y. Mryake, Women, Work, Family, and the State in Japan, 1868-1990, Santa Cruz 1991, s. 271.

79 Wspótczesna kobieta japońska, s. 9-10. 
Książnica Pomorska w Szczecinie. Zbiory specjalne, sygn. 3399, Polska działalność gospodarcza na Dalekim Wschodzie. Przeszłość i przyszłość organizacji wywozu, Tadeusz Szukiewicz, Kraków 1949, k. 157.

\section{Opracowania}

Анучин В.А., Географические очерки Маньчжурии, Москва 1948.

Borysiewicz M., Przedsiębiorczość polska w Harbinie w latach 1898-1945, [w:] Polska i sąsiedzi na przestrzeni wieków. Prace doktorantów historii II. Na wojnie i w czasach pokoju, red. W. Skóra, A. Teterycz-Puzio, Słupsk: Akademia Pomorska w Słupsku 2018.

Bureau of Information Manchukuo State Council, An Outline of the Manchukuo Empire, 1939, Dairen 1939.

Bursewicz S., Mandżuria i Syberia w piśmiennictwie Konstantego Symonolewicza, [w:] Problemy społeczno-gospodarcze Syberii, red. M. Pietrasiak, M. Stańczyk, Łódź: UŁ 2011.

CAbanowski M., Tajemnice Mandżurii. Polacy w Harbinie, Warszawa: Muzeum Niepodległości 1993.

Confucian Personalities, eds. A.F. Wright, D. Twitchett, Stanford 1962.

Davison C., The Japanese Earthquake of 1923, London 1931.

EBrey P.B., Women and the Family in Chinese History, London 2002.

EPSTEIN M., The Statesman's Year-Book 1936, London 1936.

FAIrbanK J.K., Historia Chin. Nowe spojrzenie, Gdańsk: Marabut 1996.

FEnBY J., Chiny. Upadek i narodziny wielkiej potęgi, Kraków: Znak 2009.

FRÉDÉRIC L., Życie codzienne w Japonii u progu nowoczesności (1868-1912), Warszawa: PIW 1988.

Gordon A., A Modern History of Japan: From Tokugawa Times to the Present: Tokugawa Times to the Present, London 2013.

Grochowski K., Polacy na Dalekim Wschodzie, Harbin 1928.

HAINES C.M.C., International Women in Science: A Biographical Dictionary to 1950, Santa Barbara 2001.

Hansson A., Chinese Outcasts: Discrimination and Emancipation in Late Imperial China, New York 1996.

Henshall K.G., Historia Japonii, Warszawa: PWN 2011.

HinsCH B., Women in Imperial China, Lanham 2016.

HiRATSUKA R., In the Beginning, Woman was the Sun: The Autobiography of a Japanese Feminist, New York 2006.

Hunter B., The Statesman's Year-Book 1998, London 1998.

Imagining the People: Chinese Intellectuals and the Concept of Citizenship, 1890-1920, eds. J.A. Fogel, P.G. Zarrow, London 1997.

IMIELIŃSKI K., Sekrety seksu, Warszawa: Polczek 1990.

ImIELIŃSKi K., Seksuologia. Mitologia. Historia. Kultura, Warszawa: PWN 1989.

Japan. Department of Education, Annual Report of the Minister of State for Education, 1935, Tokyo 1935. 
Japan. Department of Education, Annual Report of the Minister of State for Education, 1937, Tokyo 1937.

Japan Encyclopedia, eds. L.F. Nussbaum, K. Roth, London 2002.

JEFFreys E., Sex and Sexuality in China, London 2006.

KAJDAŃSKI E., Chiny. Leksykon. Historia, gospodarka, kultura, Warszawa: Książka i Wiedza 2005.

KAJDAŃSKi E., Korytarz. Burzliwe dzieje Kolei Wschodniochińskiej 1898-1998, Warszawa: Książka i Wiedza 2000.

KarolczaK K., System konstytucyjny Japonii, Warszawa: Wydawnictwo Sejmowe 1999.

Ko D., Every Step a Lotus: Shoes for Bound Feet, Los Angeles 2001.

Ko D., Women's History: Asia, [w:] Encyclopedia of Historians and Historical Writing, vol. 2, ed. K. Boyd, London 1999.

Kość A., Filozoficzne podstawy prawa japońskiego w perspektywie historycznej, Lublin: RW KUL 2001

LatTimore O., The Mongols of Manchuria, New York 1934.

Leksykon państw świata '94/95, oprac. zespół pod kier. M.B. Michalika, Warszawa: Kronika, M.B. Michalik 1994.

Łoza S., Czy wiesz kto to jest?, Warszawa 1938.

Mann S., Precious Records: Women in China's Long Eighteenth Century, Stanford 1997.

MrYaKe Y., Women, Work, Family, and the State in Japan, 1868-1990, Santa Cruz 1991.

Moustafine M., Secrets and Spies. The Harbin Files, London 2002.

NAToŃski B., Wojciech Męciński, [w:] Gdy Europa szukała Azji, red. F. Plattner, Kraków: Wydawnictwo Apostolstwa Modlitwy 1975.

NGUYEN D., Polscy misjonarze na Dalekim Wschodzie w XVII-XVIII wieku, Warszawa: Neriton 2006.

PADACZ W., Z polskiej gleby, Kraków: WAM 1973.

Peking United International Famine Relief Committee, The North China Famine of 19201921, Peking 1922.

Петров В.П., Город на Сунгари, Вашингтон 1984.

Perry E.J., Challenging the Mandate of Heaven. Social Protest and State Power in China, Armonk 2002.

Perry E.J., Rebels and Revolutionaries in North China, 1845-1945, Stanford 1980.

Polit J., Chiny, Warszawa: Trio 2004.

Polo M., Opisanie świata, Warszawa: W.A.B. 1954.

Putnam Weale B.L., The Coming Struggle in Eastern Asia, London 1908.

Renshaw J.R., Kimono in the Boardroom. The Invisible Evolution of Japanese Women Managers, New York 1999.

REYMAn E.J., Encyklopedia nauk politycznych, t. III, Warszawa 1938.

Rosentee L.L., Confucianism and Women. A Philosophical Interpretation, Albany 2006.

RubaCH-KuCZewsKa J., Życie po japońsku, Warszawa: Iskry 1985.

Scott-Keltie J., The Statesman's Year-Book, London 1885. 
Shirokogorov S.M., Social organization of the Manchus. A study of the Manchu clan organization, New York 1924.

Sidichmienow W.J., Chiny. Karty przeszłości, Warszawa: Iskry 1978.

SKóRA W., Organizacja i pierwszy okres działalności polskich konsulatów w Harbinie i Władywostoku w latach 1920-1924, [w:] Polskie ślady na Dalekim Wschodzie. Polacy w Harbinie, red. A. Furier, Szczecin: Książnica Pomorska im. S. Staszica 2008.

SkóRA W., Placówki MSZ Drugiej Rzeczypospolitej w Harbinie w latach 1920-1941 na tle dziejów Chin i Mandżurii (Mandżukuo). Szkic do problemu, [w:] Na szlakach dwóch światów. Studia ofiarowane Profesorowi Jerzemu Hauzińskiemu w 45-lecie pracy naukowej i dydaktycznej, red. A. Teterycz-Puzio, Słupsk: Wydawnictwo Naukowe Akademii Pomorskiej 2016.

STEInBERG S., The Statesman's Year-Book, London 1959.

Stephan J.J., The Russian Fascists. Tragedy and Farce in Exile, 1925-1945, London 1978. Studia i materiały do dziejów miasta Białegostoku, eds. J. Joka, J. Antoniewicz, H. Majecki, Białystok: Białostockie Towarzystwo Naukowe 1968.

Symonolewicz K., Miraże mandżurskie, Warszawa 1932.

SzUBIAKIEWICZ T., Japonia-Polska coraz bliżej siebie, Warszawa: Biblioteka Narodowa 2002. TANG L., China facts and fancies, Shanghai 1936.

TANNAHILl R., Historia seksu, Warszawa: Książka i Wiedza 2001.

The Birth of Chinese Feminism: Essential Texts in Transnational Theory, eds. L.H. Liu, R.E. Karl, D. Ko, New York 2013.

THeISS W., Dzieci syberyjskie. Dzieje polskich dzieci repatriowanych z Syberii i Mandżurii w latach 1919-1923, Warszawa: UW 1992.

Totman C., Historia Japonii, Kraków: Wydawnictwo UJ 2009.

Tuкотомi K., Namiko, tłum. J. Marlicz, Poznań 1924.

Turner B., The Statesman's Year-Book 2007, New York 2007.

United States War Department, Civil Affairs Handbook, Japan, Prefectural Studies, Washington 1945.

WANG R.R., Images of Women in Chinese Thought and Culture: Writings from the Pre-Qin Period Through the Song Dynasty, Cambridge 2003.

Winiarz A., Główne kierunki i formy aktywności Polaków w Mandżurii w latach 18971949, [w:] Polskie ślady na Dalekim Wschodzie. Polacy w Harbinie, red. A. Furier, Szczecin: Książnica Pomorska im. S. Staszica 2008.

WitTe S.Y., The Memoirs of Count Witte, tłum. A. Yarmolinsky, Garden City 1921.

Wróbel Z., Dzieje erotyzmu, t. III: Uczta trzech szczytów. Chińskie obyczaje erotyczne, Bydgoszcz: Arcanus 2000.

Wychodźstwo polskie w poszczególnych krajach. Materiały opracowane na podstawie sprawozdań konsularnych przez referat emigracyjny w Wydziale Administracyjno-Paszportowym Departamentu Konsularnego MSZ (kwiecień 1926), Warszawa 1926.

Yao X., An Introduction to Confucianism, Cambridge 2000.

Yong-Deog K., Kolonia polska w Mandżurii 1897-1949, Kraków: Wydawnictwo Promocji Powiatu, Miasta i Gminy PROMO 2001. 
Yust W., Britannica Book of the Year 1944, London 1944.

YutANG L., My Country and My People, New York 1935.

\section{Czasopisma}

Arkin F., Kobieta Dalekiego Wschodu, „Daleki Wschód” 1934, nr 9-12.

ARKIN F., Kobieta Dalekiego Wschodu, „Daleki Wschód” 1935, nr 1.

„Biuletyn Polskiej Izby Handlowej w Harbinie” 1932, nr 5.

„China Monthly Review” 1919, t. 8.

„Chinese Recorder” 1898, t. 29.

„Echo z Dalekiego Wschodu” 1934, nr 3.

Edwards L., Women's Suffrage in China: Challenging Scholarly Conventions, „Pacific Historical Review" 69(2000), nr 4.

GaO X., Women Existing for Men: Confucianism and Social Injustice against Women in China, „Race, Gender and Class” 3(2003).

GoDsKa I., Kobieta w cyfrach, „Echo z Dalekiego Wschodu” 1938, nr 6.

Grajdanzev A.J., The Mongols of Manchuria. Their tribal divisions, geographical distribution, historical relations with Manchus and Chinese, and present political problems, „Pacific Affairs” 8(1935), nr 3.

Hershatter G., Wang Z., Chinese History: A Useful Category of Gender Analysis, „American Historical Review" 113(2008), nr 5.

JabŁoŃSKa A., KrąKOwski K., Z dziejów Polonii Harbińskiej, „Przegląd Orientalistyczny” 1961, nr 2(38).

KotaŃsKi W., Seyfried K., Stosunki kulturalne między Polską i Japonią, „Przegląd Orientalistyczny" $1961, \mathrm{nr} 2$.

Kozıowski Z., Małżeństwo w Chinach, „Echo z Dalekiego Wschodu” 1939, nr 6.

LEE E., The Great Kantō Earthquake and "Life-rationalization" by modern Japanese women, „Asian Journal of Women’s Studies” 21(2015), nr 1.

LEE W.Y., Women's Education in Traditional and Modern China, „Women's History Review" 4(1995), nr 1.

„Listy Harbińskie” 1932, nr 1 i nr 5

Manchuria as a demographic frontier, „Population Index”11(1945), nr 4.

Molony B., Women's Rights, Feminism, and Suffrage in Japan, 1870-1925, „The Pacific Historical Review" 69(2000), nr 4.

NowaK-KieŁbikowa M., Japan and China in Polish Diplomacy, 1918-1939 (An Attempted Outline), „Acta Poloniae Historica” 49(1984).

Nuita Y., Fusae Ichikawa: Japanese Women Suffragist, „Frontiers: A Journal of Women Studies" 3(1978), nr 3.

„Official Gazette. English Edition” 1948, t. 526.

„Praca. Pismo Postępowe i Demokratyczne” 1918, nr 8.

ReIch P., FukUdA A., Japan's Literary Feminists: The “Seito” Group, „Signs” 2(1976).

SCHEnCKIng J.C., The Great Kanto Earthquake and the Culture of Catastrophe and Reconstruction in 1920s Japan, ,Journal of Japanese Studies”2(2008), nr 34. 
SzYMAŃSKi J., Opieka duszpasterska nad Polakami w Harbinie, „Studia Polonijne” 2017, t. 38. Thakur R., Women's Studies in China Today, „Economic and Political Weekly” 41(2006), $\mathrm{nr} 42$.

„The Modern Review” 44(1928).

„The Spectator" 80(1898).

WANG S., The 'New Social History' in China: The Development of Women's History, „The History Teacher" 39(2006), nr 3.

Winiarz A., Działalność Polskiego Komitetu Opiekuńczego w Harbinie (1942-1945), „Rocznik Polonijny” 1984-1985.

Winiarz A., Bibliografia prasy polskiej na Dalekim Wschodzie w latach 1917-1949, „Kwartalnik Historii Prasy Polskiej” 25(1986), nr 1.

Współczesna kobieta japońska, „Echo z Dalekiego Wschodu” 1939, nr 2, s. 9.

ZAJĄCZKOWSKI R., Literatura polska w Japonii, „Roczniki Kulturoznawcze” 7(2016), nr 3.

\section{SYTUACJA SPOŁECZNA KOBIET NA DALEKIM WSCHODZIE UTRWALONA W CZASOPISMACH I WSPOMNIENIACH POLAKÓW NA PRZEŁOMIE XIX I XX WIEKU}

\section{Streszczenie}

Walka z niesprawiedliwością względem kobiet toczyła się na Dalekim Wschodzie od setek lat, jednak ich położenie uległo poprawie dopiero w pierwszych dekadach XX wieku. Bodźcem do usamodzielnienia się tamtejszych kobiet stały się liczne przekłady literatury europejskiej z końca XIX wieku. Głównym postulatem stawianym przez rzesze Chinek i Japonek było przyznanie kobietom praw wyborczych, co stało się możliwe dopiero pod koniec lat czterdziestych XX wieku. Mimo wszystko kobiety Dalekiego Wschodu nie zrezygnowały ze swoich dążeń, uzyskując szereg znaczących praw, między innymi majątkowych, spadkowych, a także w dziedzinie nauki i pracy. Polacy z zaciekawieniem przyglądali się walce Chinek i Japonek o równouprawnienie, co uwidoczniło się w artykułach publikowanych zarówno w Polsce, jak i zagranicą.

Słowa kluczowe: prawa kobiet; Daleki Wschód; Japonia; Chiny; diaspora polska

\section{SOCIAL SITUATION OF WOMEN IN THE FAR EAST RECORDED IN MAGAZINES AND MEMORIES OF POLES AT THE TURN OF THE NINETEENTH AND TWENTIETH CENTURY}

\section{Sum mary}

The fight against injustice affecting women has been going on in the Far East for hundreds of years, however their position improved only in the first decades of the twentieth century. The stimulus for the emancipation of local women came from numerous translations of European 
literature dating back to the late nineteenth century. The main demand put forward by the masses of Chinese and Japanese women was aimed at giving them the right to vote, which turned out to be possible only at the end of the 1940. Nevertheless, women in the Far East did not give up their efforts, obtaining a number of significant rights, regarding property, inheritance, as well as education and labor. Poles were curious to watch the struggle for gender equality in China and Japan, which was largely reflected in articles published both in Poland and abroad.

Key words: women's rights; Far East; Japan; China; Polish diaspora 